\title{
Identification Research on Establishment of Marxist Mainstream Ideology in Teaching of Political and Theoretical Subject in Colleges and Universities
}

\author{
Shuangyin Li, Liya Su
}

The Central Institute for Correctional Police, Baoding, 071000, China

Keywords: Ideology and politics; Marxism; Mainstream ideology; Identity education

\begin{abstract}
With the rapid development of integrated construction, the transmission and development of Marxist mainstream ideology in China have been challenged. The identification investigation on Marxist mainstream ideology of Chinese college students finds that problems such as dilution of identity education of mainstream ideology and lack of theoretical education occur in the teaching of ideology and politics in Chinese colleges and universities, which are adverse to the further development of social mainstream ideology. Therefore, colleges and universities should attach more importance to ideological and political course, give full play to the important carrier function of ideological and political course in the establishment of identity education of Marxist mainstream ideology, strengthen students' identification for mainstream ideology, improve national cohesion and centripetal force and promote further development of socialist modernization.
\end{abstract}

\section{Introduction}

Since the $21^{\text {st }}$ century, the development trend of political multi-polarization and economic globalization has constantly strengthened and produced important influence on the construction and development of the society at each level. Under this historical background, the mainstream ideological education of college students is subject to severe social challenge. The lack of educational thought has produced important influence on value identification of mainstream ideology of college students and finally caused the lack of value ideal and belief in this aspect to a certain extent. Therefore, it is required to attach more importance to identity education of college students' mainstream ideology in ideological and political education of colleges and universities, explore methods for integrating ideological and political education and mainstream ideological education positively, gradually improve the ideological and ethical quality and political accomplishment of contemporary college students and train high-quality talents for socialist construction.

Role of ideological and political theoretical subject in colleges and universities in the improvement of identity education of college students' mainstream ideology

Positively guide college students to establish scientific and correct value recognition for mainstream ideology

Value recognition is the process of cognizing certain value in the society with a reasonable cognitive style. Individual cognition for social mainstream ideology has direct influence on the practice of social behaviors. Therefore, colleges and universities must start from students' life reality, give full play to the main function of ideological and political theoretical subject in mainstream ideological education and guide students to form correct value understanding of mainstream ideology in teaching practice by carrying out certain teaching activities appropriately. ${ }^{[1]}$ First, students should be guided to form correct understanding of ideology. Ideology mainly refers to the integration of thoughts and ideas, individual opinions and concepts related to social politics, culture and economy and covers specific patterns of manifestation in political law, ideology and morality, philosophy and religion, literature and art and other social science. For the further development of any country and nationality, it is required to establish a legal political status and system and gradually make social masses widely approve social ideology of the ruling class through publicity and education. Moreover, 
clear understandings of Chinese and foreign ideological conflicts should be maintained. Under the social trend of economic globalization development, ideological influence and culture and art gradually become important strategies used by capitalist countries to overturn socialist countries. Therefore, college students should maintain clear understandings of Chinese and foreign ideology, understand the importance of the improvement of ideological control by the Chinese government and provide spiritual guarantee for socialist construction. In addition, attention should be paid to the understanding of ideology according to national conditions and social reality of China. Social ideology has certain class historic nature. In a positive society, social mainstream ideology and common psychology of social masses can reflect the political and economic situation of the society directly or indirectly and maintain interests of a social class. The mainstream ideology of western capitalist pays attention to the publicity of universal and above-class all-people thought, considers interests of exploiting class at the ruling level and the overall interest of the state and has a great gap with the value of socialist mainstream ideology with interests of proletariat as the starting point. Capitalist ideology of the western society and basic national conditions of China have a great gap. It cannot maintain fundamental interests of the masses in China.

\section{Strengthen college students' value identification for Marxist mainstream ideology}

Value identification means that social individuals can restrain their behaviors consciously with social value as the standard of conduct in the specific process of social practice. Value cognition represents college students' preliminary understanding of basic ideology in the society. Value identification formed after careful thinking about social ideology represents the sense of identity and satisfaction about social mainstream ideology and affirmation for mainstream ideology in thoughts and emotions and subjective attitude. Therefore, ideological and political theoretical subject in colleges and universities can train college students' value cognition for Marxist mainstream ideology. In essence, students are expected to experience the spiritual charm of Marxist thought and the important significance of the practice of such thought for social spiritual civilization and individual development. ${ }^{[2]}$ As the mainstream ideology of China, Marxism is a relatively scientific world view and methodology. In terms of individual self-improvement in the society, Marxist mainstream ideology plays a vital and positive role in the guidance over the establishment of college students' correct outlook on life, value, ideal and faith and conscious constraint and standardization of behaviors in the social life. In terms of the overall construction of the society, strengthening identity education for Marxist mainstream ideology can gradually improve the level of spiritual life of social masses, maintain social unity and stability and make corresponding contributions to the establishment of harmonious society.

\section{Guide college students to establish correct value ideal in social mainstream ideology}

Value ideal refers to the yearning and actual pursuit for future social mainstream value, which are gradually formed by social masses in social practical activities and might be achieved. Training college students' value cognition and identification for mainstream social ideology through ideological and political education is a basic link of identity education of Marxist mainstream social ideology for college students. The key of implementing identity education of mainstream ideology consists in the ability to transform individual value for social mainstream ideology to conscious acceptance of this ideology and willingness to practice it in social life. ${ }^{[3]}$ It is the precondition for college students practicing and internalizing social mainstream ideology consciously and gradually developing it into strong value belief. College students' value ideal not only contains their desire and yearning for future social life, but also guides the main development direction of the future society. It is an important spiritual weapon of college students when they are faced with social ideological conflicts. Only when college students have correct value ideal can they keep conscience and avoid being confused and even losing the principle of behaviors and main direction of future development when they are faced with a complicated, diversified and constantly changing world. 


\section{Strategies for establishing identity education for Marxist mainstream ideology through efficient ideological and political theoretical subject}

Strengthening college students' sense of identity for Marxist mainstream ideology through ideological and political theoretical education has gradually developed into an emphasis and difficulty of ideological and political theoretical course in colleges and universities, which reflects the high sense of responsibility and historical mission of workers of ideological and political education in colleges and universities.

First, teachers of ideological and political theoretical education course must have strong political ideal and belief and improve their ideological and political accomplishment through constant learning and development. As important spreaders of Marxist theory and actual speakers of policies of the Communist Party of China, they must have ideological and political consciousness and corresponding sense of politics, adhere to high sense of responsibility for the society and historical mission, form comprehensive, profound and systematic understandings of social ideology according to Chinese history of revolutionary struggle and the reality of political multi-polarization development under the guidance of Scientific Outlook on Development with strong ideological and political belief and enthusiasm, and produce positive influence on identity education of mainstream ideology for college students. In terms of specific ideological building, they should be good at observing and thinking about social problems carefully from the perspective of political construction, guide students' correct perseverance and objection in national political events, help students to maintain a clear political mind and practice Marxist mainstream ideology consciously in the school life and social practice in the unprecedentedly complicated field of social consciousness, and actually be good guide of college students' growth of ideological spirit. ${ }^{[4]}$ Marxist theory is the most scientific world view and methodology in the political theory of China. Certain time is required for profound understanding and mastery of the theory. Therefore, ideological and political teachers should establish scientific teaching concepts in work, carry out corresponding scientific research activities positively, establish learning exchange platform, drive teaching research with scientific research and provide certain support and vigor for further development of teaching work.

Second, it is required to guide ideological and political theoretical education with socialist core value system and gradually improve the ability of college students' value judgment and selection. Psychology and information spreading in the modern society point out that people pay attention to those thoughts and opinions consistent with their own thinking set and ideal and belief instinctively in social life, and neglect the information inconsistent with their thinking consciousness. To a certain extent, this shows that only by making college students develop a social ideology consistent with their own value in the teaching of ideological and political theory can teachers win their idea identity. In the current stage, Chinese society is in the transitional period with fierce collision of various kinds of ideology. College students' value is also influenced. They become confused. A positive ideological value is required urgently for their positive guidance. As the main site for college students' study of socialist core value, ideological and political theoretical education must make college students actually approve Marxist mainstream ideology from thoughts and emotions and the rational height of world view cognition.

Third, it is required to explore the basic law of teaching of ideological and political theoretical course in colleges and universities positively and endeavor to train students' thinking mode of self dialectic analysis. The penetration of identity education of socialist mainstream ideology in ideological and political theory requires the instillation of ideology. Only instillation education can make students develop profound understandings of mainstream ideology. Lenin pointed out in his discussion that the working class cannot generate socialist democratic consciousness. Therefore, the working class can only understand and master such consciousness through external instillation education. It is impossible for college students to generate socialist mainstream ideology in thinking consciousness consciously. Therefore, teachers are required to instill such thought in ideological and political theoretical course and deepen students' cognition and understanding of mainstream ideology. ${ }^{[5]}$ However, it's worth noting that instillation education is not equal to duck-stuffing teaching which is a wishful teaching method. Instillation is an interactive teaching method. 
Duck-stuffing education neglects students' subjective initiative and individuality to a certain extent. Instillation education refers to dialogues of educational parties at ideological level, which help students clear, correct and transform their original thoughts in dialogue communication. In terms of the selection of teaching methods, political teachers should innovate the educational form appropriately during traditional inoculation based on college students' ideological development features according to their ideology of pursuing freedom and equality and objecting to hierarchy and constraint.

Finally, attention should be paid to integrate ideological and political theoretical education and red culture of China. Red culture refers to the excellent revolutionary tradition integrating revolutionary political theory, experience and spirit gradually formed in Chinese revolutionary construction under the leadership of the Communist Party of China. The penetration of ideological connotations of red culture and its unique educational value in the teaching of ideological and political course not only can help university education practice socialist core value system and Marxist mainstream ideology, but also is good for strengthening value education of college students, thus providing corresponding help for gradually improving college students' cognition of mainstream ideology. Under the current social background that internet information spreading produces great influence on the establishment of college students' ideological value, colleges and universities should penetrate identity education of mainstream ideology in educational curriculum of ideological and political theory, constantly satisfy the changing spiritual and cultural construction of Chinese college students with new educational thought and form through the expansion of ideological and political teaching contents with the transmission of campus red culture as carrier, and then strengthen the effectiveness of identity education.

\section{Conclusion}

Strengthening identity education of Marxist mainstream ideology for college students in ideological and political theoretical course can satisfy college students' identity demands for social mainstream ideology, strengthen value cognition of college students' mainstream social ideology, establish correct value ideal of mainstream socialist ideology cognition, gradually allow college students to restrain their own behaviors consciously in social life with social mainstream ideology as the code of conduct and make corresponding contributions to the construction of socialist harmonious society.

\section{References}

[1] Zhou Suqin. Analysis on College Students' Mainstream Ideology Cognition under the Situation of "Four Modernizations". Heilongjiang Researches on Higher Education, 2012,30(10):85-88.

[2] Wang Xiaochuan, Xiao Xiang. Discussions on Improvement of College Students' Mainstream Ideology Cognition through Ideological and Political Theoretical Course. China Electric Power Education, 2014(5):213-215,217.

[3] Niu Shaona, Chen Yanbin. Reasons and Countermeasures for Marxist Belief Crisis of Postgraduates - Based on Thinking on Empirical Investigation on Some Colleges and Universities in Jiangsu. Journal of China University of Mining and Technology (Social Sciences Edition), 2013,15(1):108-111.

[4] Liu Rongqing, Zu Quan. Discussions on Main Path for Promoting Popularization of Socialist Mainstream Ideology by the Communist Party of China. Journal of Hefei University of Technology (Social Sciences Edition), 2013(5):51-56.

[5] Hu Yurong. Strengthen Identity of Marxist Mainstream Ideology. Observation and Thinking, 2014(1):41-45. 